\title{
Confronting Monetary Policy Dilemmas: The Legacy of Homer Jones
}

Beryl W. Sprinkel

This article first appeared in the March 1987 issue of Review.

Federal Reserve Bank of St. Louis Review, November/December 2013, 95(6), pp. 455-60.

I

$\mathrm{t}$ is an honor to deliver this first annual lecture in memory of Homer Jones. I first became acquainted with Homer when writing my thesis at the University of Chicago, and I found some of his writings to be particularly useful. When Homer later became Director of Research at the St. Louis Federal Reserve Bank, it was-like many things in life-not particularly momentous in itself, but the implications for monetaiy economics were certainly important. In his priceless style, Harry Johnson described Homer Jones as “....an oasis in the desert that Keynesian economics and concern with credit had made of the Federal Reserve System, [and] the last outpost of classical monetary civilization in a cancerous culture of barbarian bumptiousness." Only an academic, of course, could say something like that-and about an era that fortunately has long passed at the Federal Reserve.

Homer Jones should be remembered for many things, not the least of which is the many people whose intellectual development he shaped and whose professional lives he fostered. He was one of Milton Friedman's first teachers-not in economics, but in insurance and statistics. Milton credits him for providing the inspiration that sparked his initial interest in economics, as well as something more tangible-getting him a scholarship to attend the University of Chicago. And, of course, Homer had a strong influence on the professional lives of the many economists who worked for him in his years at the St. Louis Fed.

Homer had an intense respect for the market system; that permeated both his economic analysis and his views about economic policy. His basic policy prescriptions in macroeconomics

At the time this article was written, Beryl W. Sprinkel was the chairman of the Council of Economic Advisers. His speech, given on March 26, 1987, at Washington University in St. Louis, is the first annual Homer Jones Memorial Lecture, which was co-sponsored by the Federal Reserve Bank of St. Louis, the Center for the Study of American Business at Washington University, and the St. Louis chapter of the National Association of Business Economists.

This article has been reformatted since its original publication in Review: Sprinkel, Beryl W. "Confronting Monetary Policy Dilemmas: The Legacy of Homer Jones." Federal Reserve Bank of St. Louis Review, March 1987, pp. 5-8; http://research.stlouisfed.org/publications/review/87/03/Confronting Mar1987.pdf.

(c) 2013, The Federal Reserve Bank of St. Louis. The views expressed in this article are those of the author(s) and do not necessarily reflect the views of the Federal Reserve System, the Board of Governors, or the regional Federal Reserve Banks. Articles may be reprinted, reproduced, published, distributed, displayed, and transmitted in their entirety if copyright notice, author name(s), and full citation are included. Abstracts, synopses, and other derivative works may be made only with prior written permission of the Federal Reserve Bank of St. Louis. 


\section{Sprinkel}

reflected this free market orientation: a distrust of the efficacy of fine-tuning and a fundamental belief in the inherent stability of a free market economy. His reliance on the market approach to problems also extended to international issues, labor market issues, and regulatory policy. From my perspective, the extent to which such principles have become more generally accepted as a basis for public policy decisions is remarkable, not only in the United States, but in other countries as well. Both as an Undersecretary at Treasury and as CEA [Council of Economic Advisers] Chairman, I have been involved, along with officials from other governments, in policy discussions on issues ranging from agriculture to tax reform. In governments around the world, there is a greater recognition of the efficiency of the market system in pricing goods and allocating resources. While much progress can still be made toward improving public policy analysis and discussion, the movement toward greater reliance on market forces is one I applaud, as I am sure Homer would as well.

One particular area where we have made substantial progress by relying on market forces is in the deregulation of financial markets and institutions. Regulations on interest rates paid by financial institutions to their depositors have been eliminated. Restrictions on competition within classes of financial institutions and between different classes have been reduced. In this area, however, more needs to be accomplished, and I suspect that Homer would share my desire to see rapid progress on the administration's proposals for further financial market deregulation.

It was difficult to be around Homer without learning a great deal from him. He had a remarkable ability to focus on the practical issues and an impatience with intellectual pretense and academic irrelevancy. His technique was to put questions to you-always pertinent questions, frequently penetrating questions, sometimes relentless questions. In so doing, he forced you to understand and articulate what you knew, while discovering what you did not know. He had a truly unusual ability to stimulate you to search for the answers. In the St. Louis Fed Research Department, I am sure that many promising ideas were hatched, many empirical relations were tested, and many influential articles resulted directly from Homer's inquiring mind and his ability to transmit that interest to others.

The products of Homer Jones's style and approach at the St. Louis Fed are well known and well respected. The weekly and monthly publications of the Research Department, which have now become standard references for everyone from undergraduates to White House officials, were initially Homer's products. The St. Louis Fed Research Department became one of the most prominent in the country and its monthly Review became widely respected and earned the stature of a professional journal. The metamorphosis of the Research Department, its role in promoting policy-related research and in providing an alternative point of view within the System was what Karl Brunner has labeled "a remarkable institutional event," made more remarkable and more influential because it occurred within the System itself.

Given the nature of Homer Jones's legacy, it is ironic - and perhaps fitting — that we are gathered here to honor his contributions at a time when there are so many unanswered questions about the conduct of monetary policy. The policy issues we face today are different from those debated by Homer. Most analysts now accept the important role of monetary policy in economic performance. Most economists acknowledge an important relation between changes in money growth and economic activity, although in recent years there has been much more uncertainty 
about the precise form of that once-reliable relationship. Few doubt, at least in general terms, the long-run link between money growth and inflation. Rather than those fundamental issues that we debated in the 1950s and 1960s, the policy challenges of today relate to the changed environment in which monetary policy is now conducted.

In the four years since this expansion began, there have been substantial changes in both the institutional and economic environment in which monetary policy must be designed and implemented. These developments are well known to this audience. The inflation rate-excluding the effects of the oil price declines in 1988-has been cut to one-third the 1980 rate. Similarly, interest rates are one-third to one-half their 1980 levels. Financial deregulation has changed the institutional structure in which monetary policy is conducted. In this decade, the introduction of NOW [negotiable orders of withdrawal] and money market accounts has significantly altered the composition of the monetary aggregates, and the relaxation of restrictions on deposit interest rates has led to the inclusion in M1 of interest-bearing deposits which pay market-determined rates of return.

These developments-and possibly others-appear to be affecting the basic relation between money and nominal GNP [gross national product] growth as indicated by the behavior of the "velocity" of money. Specifically, while there have always been sizable fluctuations in velocity from one quarter to the next, over longer periods velocity rose at a reasonably predictable rate of about 3 percent per year between 1947 and 1981. Since the cyclical peak of 1981, however, velocity has declined at more than a 3 percent annual rate.

There are a number of plausible explanations for this decline in velocity. However, with the limited data available, it is difficult to reach definitive conclusions.

To my knowledge, the most promising lines of empirical research attempt to relate velocity declines to the decline in inflation and interest rates and to their effect on the interest-elasticity of the demand for money. In the recent period of declining interest rates, the opportunity cost of holding the highly liquid balances in M1 has fallen, thereby raising desired M1 balances and suppressing velocity. As market interest rates change, the public response in terms of moving in and out of Ml balances is difficult to predict. In part this is because we have relatively little experience with deregulated deposit rates and also because it is not clear how depository institutions will adjust deposit rates to changes in market rates. This implies continued uncertainty about the future behavior of velocity.

Over most of this expansion we have had monetary growth - particularly in M1 — that, based on the historical relation with nominal spending and inflation, would be viewed as excessive. Yet, we have not had the short-run surge in real growth and nominal spending that would be expected from such high M1 growth. We are therefore left with a difficult dilemma about the implications of recent $\mathrm{M} 1$ growth for future inflation. On that issue, a wide range of opinion exists. Some forecasters - many of whom are long-time friends of mine-foresee a major resurgence of inflation resulting from the monetary growth of the past two years. Other analysts discount recent $\mathrm{M} 1$ growth as being the result of financial deregulation, disinflation, declining interest rates, or some combination of such factors.

It is interesting to note, however, that even those who rely most heavily on money growth as a forecasting tool are not predicting an inflation as high as would be implied by historical 
velocity behavior. The Shadow Open Market Committee, for example, forecasts inflation and nominal GNP growth consistent with the assumption that velocity growth remains well below its postwar trend growth path. Neither the most recent Blue Chip forecasts nor the administration's economic projections reflect the expectation that recent M1 growth will be translated into spending and inflation in accordance with historical velocity behavior. In fact, I know of no serious, current forecast that does not implicitly assume continued atypical velocity behavior, at least over the coming year.

These and related questions have made the conduct of monetary policy particularly difficult over the course of this expansion. It is my judgment that in the context of considerable uncertainty about velocity growth, the Federal Reserve has done a reasonably good job balancing the risk of renewed inflation against the risks associated with too little money growth. I do not believe, however, that we can afford to be complacent about a long continuation of the money growth we have experienced in recent years. The Reagan administration is committed not just to reducing inflation, but to the ultimate goal of restoring price stability. By distorting price signals and eroding productive incentives, inflation is a powerful deterrent to long-term real growth and job creation. Moreover, high inflation ultimately brings the high costs of reducing the inflation rate-costs that our economy paid in the recession of 1981-82 and that are still being paid in such sectors of our economy as agriculture and energy. Given the inevitable costs associated with reducing inflation and the importance to long-term prosperity of keeping inflation under control, it would be a policy blunder to allow inflation to reaccelerate.

In assessing monetary policy, it is important to recognize what it can and cannot accomplish. It cannot smooth out all short-term fluctuations in output, employment, or the price level. Nor can it sustain real growth rates that consistently exceed the economy's potential-as determined by underlying rates of productivity and population growth and trends in labor force participation. Monetary policy, however, can deliver reasonable stability of the price level in the longer run and can avoid being an additional important cause of disturbances to output and employment growth in the shorter run.

Monetary policy has contributed to the success we have enjoyed in resolving the critical problems that confronted the U.S. economy when President Reagan assumed office. The annual inflation rate has been cut by two-thirds-from double-digit levels in 1979-80 to about 4 percent for the past four years. Interest rates generally have fallen to about one-third of the levels of six years ago.The economy is now in the 52nd month of what will soon become the longest peacetime expansion since World War II. As this expansion has proceeded, in contrast with the experience in earlier expansions, the inflation rate and interest rates have shown no tendency to rise and to bring about the strains that led to the ends of earlier expansions. Thus, the destructive sequence of business cycles with progressively rising inflation and interest rates has been broken, and the foundation has been laid for sustainable real growth with moderate inflation.

The problems that remain in the U.S. economy are not primarily problems that can be addressed with monetary policy—beyond its normal role in gradually moving toward the goal of long-run price stability, while avoiding being a source of macroeconomic disturbance. In particular, the critical and related problems of the large federal deficit and of the large U.S. trade deficit cannot be resolved by monetary policy. 
The federal government has a deficit because the share of federal spending in GNP has risen well above the average share that federal revenue has maintained in GNP for three decades. The solution is to restrain the absolute growth of federal spending, while economic growth raises the absolute level of federal revenues.

The United States has a trade deficit because we as a nation spend more than the value of what we produce. To finance this excessive spending, we import capital from the rest of the world in an amount that corresponds to our current account deficit. Excessive federal spending and corresponding federal borrowing are an important part of the problem-and reversing them is an important part of the solution. So too are stronger, internally generated growth and more open trade policies on the part of our trading partners. We require a coordinated approach to reducing international payments imbalances in an environment that maintains world economic growth.

I could discuss further the problems of our fiscal and trade deficits, as well as other problems of the U.S. economy. However, my experience even before I went to Washington taught me brevity is a virtue-perhaps a virtue even more appreciated by audiences than by speakers.

Among the things that I have learned in Washington—and there are many-one of the most important is how simple things look from the outside, but how much more difficult it is when you actually have to take action and assume the responsibility for its effect on people's well-being. In policymaking, things are seldom simple. Certainly in the macroeconomic field, where policy tools are blunt and forecasts are frequently wrong, there are risks associated with any policy decision. Ultimately, policymakers must face the question: What are the consequences if I am wrong? If nothing else, it is a humbling experience.

No one in my memory had learned this lesson better than Homer Jones. His humble and unpretentious personal style was reflected in his professional approach: Take nothing for granted and believe only what can be justified by the data. So what would Homer have to say about the current dilemma? I like to tell my staff-some of them think I tell them too often-that I'm from the "Show-Me" State. I want to see the data to support a conclusion. While Homer wasn't born in Missouri as I was, he certainly adopted the show-me attitude about economic issues. Knowing his insistence that policy be based on empirically tested relations, he surely would share the concerns about high money growth over the past few years. He surely would not easily discard long-term empirical relationships. But I also doubt that he would counsel ignoring current developments as they have varied dramatically from historical patterns.

Given the aberrant behavior of velocity over the past four years or so, policymakers have little alternative but to supplement the information provided by the monetary aggregates with other relevant data. To me, this implies looking in addition at interest rates, exchange rates, sensitive prices such as gold and other commodities, forward markets, and measures of real economic activity for signals as to the meaning and implication of money growth and monetary policy actions. The limitations and deficiencies of these data as guides to monetary policy are great and are well known, and I will not recount them here. It is not an ideal approach, but I see no workable alternative at the present time. To date, I know of no completely satisfactory explanation of what has happened to velocity. When more time has passed in a deregulated and lowinflation environment, I am confident that reliable relationships will re-emerge, which I trust 
can be identified by appropriate empirical testing. In the interim, policy decisions must be made that properly balance the risks to the economy of alternatively too much or too little money growth. As a nation, we cannot afford the pain and disruption of allowing inflation to resurge, nor can we afford to risk the economic consequences of excessive monetary restriction.

In a sense, the dilemmas and frustrations of today's policy issues lead those of us who knew Homer Jones to plead, "Homer, where are you when we need you?" For today, we surely could use his quiet, reasoned assessment of the issues.

Many people accomplish important things in their lives. I wonder whether there are not more important things to be remembered for than what you invented, discovered, wrote, or built. It may be a more-lasting legacy to be remembered for how you influenced the thinking and accomplishments of others. Among those of us who call ourselves monetary economists, few can claim that legacy as readily as Homer Jones. 